\title{
Effects of sustained isometric handgrip on praecordial accelerocardiogram in normal subjects and in patients with heart disease
}

\author{
Leslie Hume, ${ }^{1}$ John B. Irving, Arthur H. Kitchin, and Stuart R. Reuben \\ From the Department of Medicine, Edinburgh University, Western General Hospital, Edinburgh
}

The effects of isometric exercise on the maximum amplitude of the praecordial accelerocardiogram (as represented by the DE deflection) have been compared in 6 normal subjects (group I), I 2 patients with aortic stenosis (group 2), and I6 patients with myocardial disease (group 3). Whereas the tachycardia and pressor effects of isometric exercise were identical in all three groups, the normal subjects showed a significant decrease in $D E$ during handgrip of $10 \pm 4$ per cent $(P<0.05)$ as compared with the insignificant increases of $8.5 \pm 6$ per cent $(P>0.5)$, and $4 \pm 3.5$ per cent $(P>0.3)$ observed in the patients in groups 2 and 3 . This response in the normal subjects differed significantly from the responses observed in the patients in groups $2(P<0.02)$ and $3(P<0.01)$.

Of the patients in each of groups 2 and 3,50 per cent responded abnormally to handgrip in that they showed a significant increase in DE. In the patients with aortic stenosis this subgroup of patients differed from the remainder in that they had a higher resting cardiac index $(P<0.05)$. In the patients with myocardial disease this subgroup was characterized by a significantly lower resting left ventricular end-diastolic pressure $(P<$ 0.02). It seems, therefore, that those patients who increase $D E$ in response to handgrip tend to have better left ventricular function at rest than those who do not. We suggest that this may be because of increased beta adrenergic activity at rest and during isometric exercise in the subgroup who respond to handgrip with an increase in $D E$.

Animal work has shown that peak acceleration of blood flow in the ascending aorta is highly sensitive to small changes in left ventricular contractility which are insufficient to cause changes in stroke volume or systemic blood pressure (Chung, Chamberlain, and Seed, 1974; Noble, Trenchard, and Guz, 1966a; Reuben and Littler, 1973; Winter et al., 1967). It has also been shown in the dog that changes in the maximum amplitude of the praecordial accelerocardiogram correlate closely with changes in peak aortic acceleration in response to a wide range of manoeuvres (Reuben and Littler, 1973). Furthermore, it appears that both are relatively independent of heart rate and ventricular loading, at least in the intact organism (Noble et al., 1972; Noble, Trenchard, and Guz, 1966a, b; Reuben and Littler, 1973).

Received 30 December 1974.

${ }^{1}$ In receipt of a University of Edinburgh Faculty of Medicine Research Scholarship. Present address: The Deaconess Hospital, Edinburgh, Scotland.
Isometric exercise, in the form of sustained handgrip, has been widely used as a stress test in cardiac laboratories for the detection of impaired left ventricular function (Helfant, De Villa, and Meister, I97I; Kivowitz et al., I97I; Krayenbuehl et al., 1972, 1973). Using the non-invasive technique of praecordial accelerocardiography we have previously demonstrated, in normal subjects, that the response to isometric exercise is independent of beta adrenergic mechanisms (Hume, Irving, and Reuben, 1974). In the present paper we compare the changes which we have observed in the maximum amplitude of the accelerocardiogram during handgrip in normal subjects and in patients with heart disease.

\section{Subjects and methods}

The six normal subjects (group I), who performed handgrip without cardiac catheterization, were all volunteer members of staff aged between 26 and 35 years. The patients comprised 12 with dominant aortic stenosis (group 2), 3 of whom had mild aortic regurgitation and 2 of whom had coexistent coronary artery disease; and 16 
with myocardial disease (group 3) caused by coronary atherosclerosis in 13 and idiopathic congestive cardiomyopathy in 3. The mean age $( \pm S D)$ of the patients in group 2 was $55.9 \pm 9.9$ years, and in group $3,48.4 \pm 8.6$ years. All patients were in sinus rhythm at the time of the study and none had clinical or haemodynamic evidence of mitral valve disease. Resting haemodynamic data are summarized in Tables $I$ to 3 . Of the 12 patients in group 2, Io had electrocardiographic evidence of left ventricular hypertrophy. Left ventriculography was performed with the patients of group 3 in the right anterior oblique position and showed a dyskinetic area in 4 (Table $\mathrm{I}$ ). Coronary arteriography was performed by the Judkins technique (Judkins, 1968). Of the patients in group 3, 8

TABLE I Resting catheterization data

\begin{tabular}{|c|c|c|c|c|c|c|}
\hline \multicolumn{4}{|c|}{ Group 2 (aortic stenosis) } & \multicolumn{3}{|c|}{ Group 3 (myocardial disease) } \\
\hline Case & $\begin{array}{l}\text { Aortic valve } \\
\text { gradient } \\
(m m H g)\end{array}$ & $\begin{array}{l}\text { Calculated } \\
\text { aortic valve } \\
\text { area } \\
\left(\mathrm{cm}^{2}\right)\end{array}$ & $\begin{array}{l}\text { Cardiac } \\
\text { index } \\
\left(l / \min \text { per } m^{2}\right)\end{array}$ & Case & Coronary angiography & $\begin{array}{l}\text { Contraction on left } \\
\text { ventriculography }\end{array}$ \\
\hline $\begin{array}{l}\text { GB } \\
\text { LB } \\
\text { AC } \\
\text { RC } \\
\text { JD } \\
\text { PD } \\
\text { TL } \\
\text { AM } \\
\text { HS } \\
\text { AT } \\
\text { TW } \\
\text { AW } \\
\text { Group } \\
\text { Mean } \\
\text { SEM }\end{array}$ & $\begin{array}{l}35 \\
34 \\
38 \\
79 \\
10 \\
76 \\
77 \\
60 \\
43 \\
85 \\
87 \\
49 \\
\\
56 \\
7\end{array}$ & $\begin{array}{l}0.43 \\
1.13 \\
0.65 \\
0.72 \\
- \\
0.60 \\
1.10 \\
0.53 \\
0.90 \\
0.40 \\
0.52 \\
0.95 \\
0.72 \\
0.08\end{array}$ & $\begin{array}{l}1.72 \\
2.72 \\
1.87 \\
4.18 \\
3.80 \\
2.90 \\
3.10 \\
2.40 \\
3.30 \\
2.16 \\
2.40 \\
3.49 \\
\\
2.92 \\
0.22\end{array}$ & $\begin{array}{l}\text { JA } \\
\text { DC } \\
\text { JC } \\
\text { WF } \\
\text { TG } \\
\text { JK } \\
\text { JL } \\
\text { FM } \\
\text { JM } \\
\text { CM } \\
\text { DM } \\
\text { CP } \\
\text { JR } \\
\text { JS } \\
\text { GT } \\
\text { GW }\end{array}$ & $\begin{array}{l}\text { 3-vessel disease } \\
\text { 3-vessel disease } \\
\text { 3-vessel disease } \\
\text { Normal } \\
\text { 3-vessel disease } \\
\text { 3-vessel disease } \\
\text { 3-vessel disease } \\
\text { Normal } \\
\text { I-vessel disease (LAD) } \\
\text { 3-vessel disease } \\
\text { 2-vessel disease (LAD, RCA) } \\
\text { 3-vessel disease } \\
\text { Normal } \\
\text { I-vessel disease (LAD) } \\
\text { 3-vessel disease } \\
\text { 2-vessel disease (LAD, RCA) }\end{array}$ & $\begin{array}{l}\text { Poor } \\
\text { Good } \\
\text { Good } \\
\text { Good } \\
\text { Poor } \\
\text { Good } \\
\text { Good } \\
\text { Good } \\
\text { Anterior aneurysm } \\
\text { Poor } \\
\text { Apical aneurysm } \\
\text { Anterior hypokinesis } \\
\text { Poor } \\
\text { Good } \\
\text { Good } \\
\text { Inferior hypokinesis }\end{array}$ \\
\hline
\end{tabular}

Conversion factor from Traditional to SI Units: I $\mathrm{mmHg} \approx 0.133 \mathrm{kPa}$.

TABLE 2 Effects of handgrip in group 2

\begin{tabular}{|c|c|c|c|c|c|c|c|c|c|c|c|c|c|c|}
\hline \multirow[t]{2}{*}{ Case } & \multicolumn{2}{|c|}{$\begin{array}{l}\text { Heart rate } \\
\text { (beats/min) }\end{array}$} & \multicolumn{2}{|c|}{$\begin{array}{l}\text { LV syst. press. } \\
(m m H g)\end{array}$} & \multicolumn{2}{|c|}{$\begin{array}{l}\text { Ao syst. press. } \\
(\mathrm{mmHg})\end{array}$} & \multicolumn{2}{|c|}{$\begin{array}{l}\text { Ao diast. press. } \\
(\mathrm{mmHg})\end{array}$} & \multicolumn{2}{|c|}{$\begin{array}{l}\text { LVEDP } \\
(m m H g)\end{array}$} & \multicolumn{2}{|c|}{$\underset{(m m H g / s)}{L V \max .} d p / d t$} & \multicolumn{2}{|l|}{$\begin{array}{l}D E \\
(\mu V)\end{array}$} \\
\hline & Control & Grip & Control & Grip & Control & Grip & Control & Grip & Control & Grip & Control & Grip & Control & Grip \\
\hline GB & 76 & 82 & 163 & 182 & 132 & 147 & 86 & 92 & 20 & 23 & 1870 & 2540 & IIOO & 1005 \\
\hline LB & 60 & 79 & 210 & 240 & 200 & 225 & 95 & 120 & 24 & 45 & 1890 & 3040 & 380 & 450 \\
\hline AC & 50 & 68 & 210 & 265 & 180 & 210 & 80 & 95 & 14 & 19 & 1780 & 2400 & 705 & 71 \\
\hline $\mathbf{R C}$ & 94 & 98 & 203 & 215 & 116 & 121 & 75 & 85 & 18 & 20 & 1600 & 1800 & 342 & 48 \\
\hline JD & 65 & 73 & 120 & 160 & IIO & 150 & 70 & 87 & II.5 & 19 & 1330 & 1550 & 785 & 100 \\
\hline PD & 109 & IIO & 210 & 215 & IIO & 130 & 80 & 97 & $2 I$ & 32 & 1560 & 1900 & 860 & 1020 \\
\hline TL & 62 & 76 & 230 & 320 & 167 & 245 & 72 & 98 & - & - & 2150 & 3180 & 763 & 763 \\
\hline $\mathbf{A M}$ & 72 & 81 & 220 & 258 & 105 & 134 & 65 & 75 & II. 5 & 18.5 & 500 & 620 & 470 & 55 \\
\hline HS & 94 & IOI & 150 & 172 & 82 & 93 & 61 & 72 & - & - & 2500 & 2620 & II95 & \\
\hline AT & 63 & 68 & 233 & 250 & 127 & I54 & 78 & 84 & 21 & 26 & 1450 & 1650 & 450 & 350 \\
\hline$T W$ & 81 & 83 & 240 & 250 & 140 & 155 & 90 & 100 & 15 & 15 & 1820 & 1960 & 689 & \\
\hline $\begin{array}{l}\text { AW } \\
\text { Group }\end{array}$ & 70 & 78 & 219 & 240 & 180 & 204 & 100 & III & 24 & 24 & 1580 & 1950 & 245 & 280 \\
\hline Mean & 75 & 83 & 201 & 231 & 138 & 164 & 79 & 93 & I8 & 24 & I670 & 2100 & 650 & 705 \\
\hline SEM & 5 & 4 & II & 13 & I0 & 13 & 4 & 4 & 2 & 3 & 140 & 205 & - & - \\
\hline
\end{tabular}

Conversion factor from Traditional to SI Units: I $\mathrm{mmHg} \approx 0.133 \mathrm{kPa}$. 
TABLE 3 Effects of handgrip in group 3

\begin{tabular}{|c|c|c|c|c|c|c|c|c|c|c|}
\hline \multirow[t]{2}{*}{ Case } & \multicolumn{2}{|c|}{$\begin{array}{l}\text { Heart rate } \\
\text { (beats/min) }\end{array}$} & \multicolumn{2}{|c|}{$\begin{array}{l}L V \text { syst. press. } \\
(\mathrm{mm} H g)\end{array}$} & \multicolumn{2}{|l|}{$\begin{array}{l}L V E D P \\
(m m H g)\end{array}$} & \multicolumn{2}{|c|}{$\begin{array}{l}L V \max . d p / d t \\
(m m H g / s)\end{array}$} & \multicolumn{2}{|l|}{$\begin{array}{l}D E \\
(\mu V)\end{array}$} \\
\hline & Control & Grip & Control & Grip & Control & Grip & Control & Grip & Control & Grip \\
\hline $\mathbf{J A}$ & 47 & 58 & I35 & 175 & 20 & $2 I$ & 2000 & 2000 & 670 & 695 \\
\hline DC & 63 & 69 & 120 & I55 & I5 & 20 & 1070 & II30 & 823 & 795 \\
\hline JC & 60 & 62 & I90 & 215 & I5 & 20 & 1780 & 1930 & 613 & 527 \\
\hline WF & $8 I$ & 88 & 160 & 180 & I8.5 & 25 & 960 & 1060 & 790 & 630 \\
\hline TG & 65 & 90 & 125 & I68 & I5 & 29.5 & 1820 & 2180 & 600 & 670 \\
\hline JK & 53 & 57 & 125 & 140 & 16 & 20 & II20 & 1250 & 372 & 453 \\
\hline JL & 76 & 82 & 125 & 148 & I8 & $2 I$ & 2360 & 2800 & 660 & 670 \\
\hline FM & 61 & 71 & 120 & I57 & I I & I8.5 & 2150 & 3170 & 685 & 820 \\
\hline $\mathbf{J M}$ & 76 & 80 & 120 & I30 & 22 & 28 & 870 & 1000 & 475 & 434 \\
\hline $\mathrm{CM}$ & I IO & I I3 & - & - & 31 & 40 & 1100 & II 50 & 477 & 425 \\
\hline DM & 81 & 85 & I I7 & I37 & 13.5 & i5.5 & 1390 & 1530 & 490 & 565 \\
\hline CP & 59 & 76 & II5 & I43 & 18 & 22 & 850 & 820 & 680 & 670 \\
\hline JR & 60 & 72 & 100 & I45 & 12 & $2 I$ & 845 & 1040 & 397 & 426 \\
\hline JS & 67 & 68 & I30 & 135 & 20 & 25 & 1850 & 1790 & 632 & 794 \\
\hline GT & 70 & 78 & II2 & 140 & 12 & 14 & II90 & 1300 & 562 & 585 \\
\hline $\begin{array}{l}\text { GW } \\
\text { Group }\end{array}$ & 76 & 87 & 120 & 140 & 12 & 13 & 1840 & 2780 & 370 & 430 \\
\hline Mean & 68 & 77 & 128 & I54 & 17 & 22 & 1450 & 1700 & 575 & 595 \\
\hline SEM & 4 & 4 & 6 & 6 & I & 2 & 130 & 180 & - & - \\
\hline
\end{tabular}

Conversion factor from Traditional to SI Units: I $\mathrm{mmHg} \approx 0.133 \mathrm{kPa}$.

had sustained a previous myocardial infarction and I was in cardiac failure, which was controlled by medical treatment, at the time of the study.

An electrocardiogram, recorded from praecordial leads, was displayed simultaneously with the accelerocardiogram on an ultraviolet recorder (Honeywell Recording Oscillograph, Type I 85 Mark 2). The accelerocardiogram transducer was attached to the chest wall overlying the fifth rib, internal to the apex beat, by means of an adhesive disc. All recordings were made during normal respiration, with the subjects supine.

The accelerometer is a cylindrical metal transducer, $2 \mathrm{~cm}$ in diameter, incorporating a strain gauge (Pixie Transducer, Endevco Laboratories Ltd., U.K.) on a cantilever spring, the free end of which is a $420 \mathrm{mg}$ lead bob. When an acceleration is applied to the base of the transducer, the movement of the lead bob relative to the base depends upon the mass of the bob, the stiffness of the spring, and the acceleration applied. The output of the instrument has been shown to be linear up to $0.5 \mathrm{~g}$, using analysis of pendular motion (Reuben and Littler, 1973), which is well in excess of any acceleration recorded during this study. Further details of the instrument have already been published (Bew et al., I97I; Reuben and Littler, I973).

Heart rate was calculated from the average of ro consecutive $R R$ intervals measured at a paper speed of roo $\mathrm{mm}$ per second, while the maximum amplitude of the accelerocardiogram (DE in Fig. I) was averaged over 20 consecutive beats, each measured to the nearest millimetre, at a paper speed of $25 \mathrm{~mm}$ per second. For convenience the accelerocardiogram data are expressed in microvolts $(\mu \mathrm{V})$ using a 0.5 millivolt square wave as a standard. We made no attempt to calibrate the tracings in units of acceleration because variations in chest wall thickness, transducer coupling, and position of the heart render comparison of absolute values between subjects meaningless (Reuben and Littler, I973). Furthermore, such a calibration is tedious to perform (Reuben and Littler, 1973).

The patients were studied during diagnostic cardiac catheterization after the collection of resting haemodynamic data but before angiography. On the day before catheterization each subject was familiarized with the handgrip procedure. Beta adrenergic blocking drugs were discontinued over the $\mathbf{7 2}$ hours preceding catheterization, but all other medication was administered as

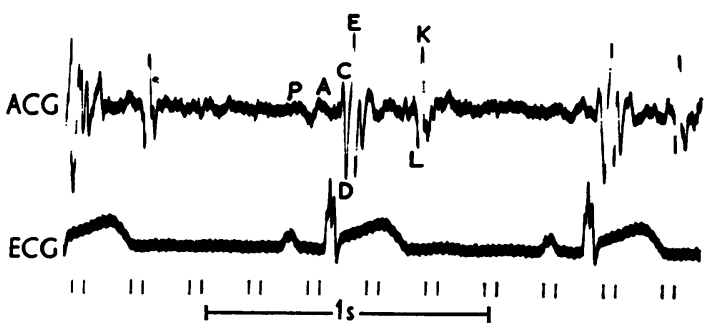

FIG. I The pattern of the praecordial accelerocardiogram.

Below: electrocardiogram.

Above: praecordial accelerocardiogram.

$D E=$ maximum amplitude of the praecordial accelerocardiogram. 
TABLE 4 Group mean changes during handgrip

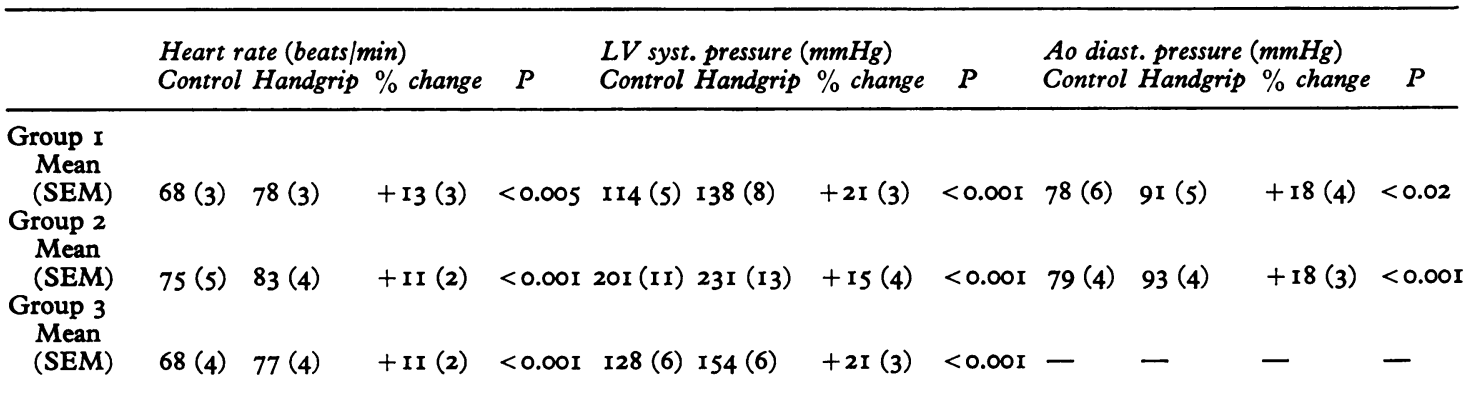

Conversion factor from Traditional to SI Units: I $\mathrm{mmHg} \approx 0.133 \mathrm{kPa}$.

usual up to the time of the studies. One hour before catheterization the patients were sedated with $5 \mathrm{mg}$ diazepam (Valium-Roche) orally.

In the patients in group 2 left ventricular pressure was recorded by means of a Brockenbrough catheter, after transseptal catheterization of the left atrium, and central aortic pressure by means of a Formocath catheter introduced into the right femoral artery by the Seldinger technique. In the patients in group 3 only left ventricular pressure was measured, after the Formocath had been manipulated across the aortic valve. Peak left ventricular systolic pressure, post ' $a$ ' wave left ventricular end-diastolic pressure, aortic systolic and diastolic pressures (group 2 only), and left ventricular maximum dp/dt, were recorded on an ultraviolet recorder (Shandon Southern Instruments Ltd., U.K.) before, during the final 30 seconds of, and 4 minutes after handgrip. Left ventricular $\mathrm{dp} / \mathrm{dt}$ was obtained by electronic differentiation of the pressure signal, using a device whose response was uniform to $50 \mathrm{~Hz}$. Resting cardiac output was measured by the indicator dilution method, using indocyanine green as the indicator and a Waters X 300 cuvette densitometer. In the patients with aortic stenosis the mean simultaneous aortic valve gradient was measured at rest and the valve area was calculated from Gorlin's formula (Gorlin and Gorlin, I95I).

In the normal subjects arterial blood pressure was measured by sphygmomanometry before, during, and after handgrip, the cuff being applied to the nonexercising arm. In the normal subjects handgrip was performed using a standard strain gauge dynamometer, whereas the patients gripped a partially inflated sphygmomanometer cuff. Each subject's maximum grip strength was first determined and each was then instructed to maintain 30 per cent maximum voluntary contraction for 3 minutes, a level of isometric exercise which has previously been shown to consistently elicit increases in heart rate and blood pressure (Fisher et al., 1973; Kivowitz et al., 1971; Payne, Horwitz, and Mullins, 1973). Care was taken to ensure that the subjects did not perform a Valsalva manoeuvre, as empha- sized in previous studies (Fisher et al., 1973; Helfant et al., 1971; Krayenbuehl et al., 1973).

The changes which occurred during handgrip are expressed as the mean change for the group \pm one standard error of the mean. Statistical analysis was performed by Student's t-test.

\section{Results}

The results are summarized in Tables 2 to 6 and Fig. 2.

\section{A. Heart rate}

In the normal subjects (group I) handgrip increased group mean heart rate from 68 to 78 beats a minute, an increase of $13 \pm 3$ per cent $(P<0.005)$.

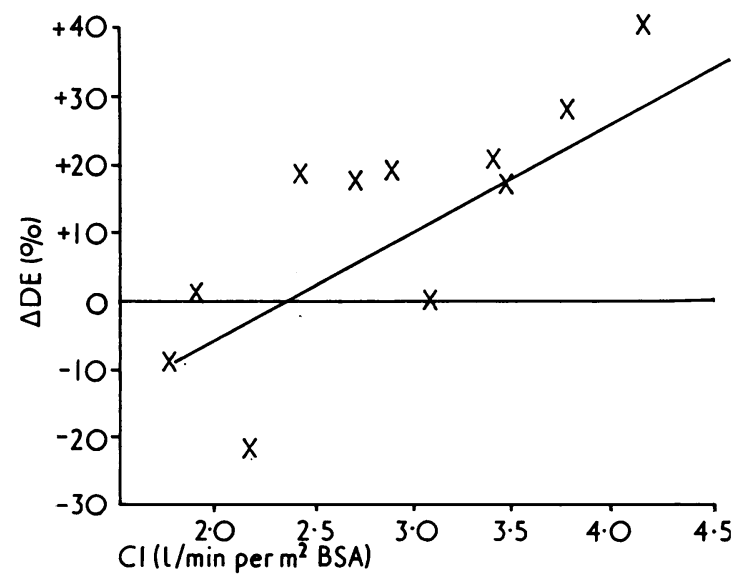

FIG. 2 Correlation between the percentage change in the maximum amplitude of the praecordial accelerocardiogram during handgrip $(\triangle D E)$ and resting cardiac index in patients with aortic stenosis. Regression equation: $\triangle D E=14.9 C I-35 r=0.79$, $P<0.01$. 


\begin{tabular}{|c|c|c|c|c|c|c|c|c|c|c|c|}
\hline $\begin{array}{l}L V \max d p \mid \\
\text { Control }\end{array}$ & $\begin{array}{c}\text { dt }(\mathrm{mmHg} / \mathrm{s}) \\
\text { Handgrip }\end{array}$ & $\%$ change & $P$ & $\begin{array}{l}\text { LVEDP } \\
\text { Control }\end{array}$ & $\begin{array}{l}\text { mmHg) } \\
\quad \text { Handgrip }\end{array}$ & $\%$ change & $P$ & $\begin{array}{l}D E(\mu V) \\
\text { Control }\end{array}$ & Handgrip & $\%$ change & $P$ \\
\hline - & - & - & - & - & - & - & - & 680 & 610 & - IO (4) & $<0.05$ \\
\hline 1670 (140) & $2100(205)$ & $+25(5)$ & $<0.001$ & $18(2)$ & 24 (3) & $+35(9)$ & $<0.01$ & 650 & 705 & $+8.5(6)$ & $\begin{array}{r}>0.5 \\
\text { NS }\end{array}$ \\
\hline $1450(130)$ & $1700(180)$ & $+16(5)$ & $<0.005$ & $17(1)$ & $22(2)$ & $+33(6)$ & $<0.001$ & 575 & 595 & $+4(4)$ & $\begin{array}{c}>0.3 \\
\text { NS }\end{array}$ \\
\hline
\end{tabular}

In the patients in group 2 mean heart rate increased from 75 to 83 beats a minute, a change of $I I \pm 2$ per cent $(P<0.001)$ and in group 3 mean heart rate increased from 68 to 77 beats a minute, a change of II \pm 2 per cent $(P<0.00$ I) (Tables 2 to 4$)$. There were no significant differences in magnitude of induced tachycardia between the groups.

\section{B. Blood pressure}

In the normal subjects group mean systolic blood pressure increased from $\mathrm{II} 4$ to $138 \mathrm{mmHg}$ ( 15.2 to $18.4 \mathrm{kPa})$, a change of $21 \pm 3$ per cent $(P<0.001)$. In group 2 the average left ventricular systolic pressure increased from 201 to $231 \mathrm{mmHg}(26.7$ to $30.7 \mathrm{kPa})$, a change of $15 \pm 4$ per cent $(\mathrm{P}<0.00 \mathrm{I})$, and in group 3 left ventricular systolic pressure increased from 128 to $154 \mathrm{mmHg}$ ( 17.0 to $20.5 \mathrm{kPa}$ ), a mean increase of $21 \pm 3$ per cent $(P<0.001)$. In group I diastolic blood pressure increased from a group mean value of 78 to $91 \mathrm{mmHg}$ (10.3 to 12.I $\mathrm{kPa})$, a change of $18 \pm 4$ per cent $(P<0.02)$, and in group 2 aortic diastolic pressure increased from 79 to $93 \mathrm{mmHg}$ (I0.5 to $12.4 \mathrm{kPa}$ ), a change of $18 \pm 3$ per cent $(P<0.001)$ (Tables 2 to 4$)$. Again, there were no significant differences in pressor response to handgrip between the groups.

\section{Maximum dp/dt}

Left ventricular maximum dp/dt increased by $25 \pm 5$ per cent, from a group mean value of 1670 to 2100 $\mathrm{mmHg}$ (222 to $279 \mathrm{kPa}$ ) per second in group 2 $(\mathrm{P}<0.00 \mathrm{I})$, and by $\mathrm{I} 6 \pm 5$ per cent, from 1450 to $1700 \mathrm{mmHg}$ (193 to $226 \mathrm{kPa}$ ) per second $(\mathrm{P}<0.005$ ) in group 3 (Tables 2 to 4 ). There was no significant difference between groups 2 and 3 with respect to the rise in left ventricular maximum $\mathrm{dp} / \mathrm{dt}(\mathbf{P}>0.5)$.

\section{Left ventricular end-diastolic pressure}

Group mean end-diastolic pressure increased from 18 to $24 \mathrm{mmHg}(2.4$ to $3.2 \mathrm{kPa})$ in group 2 , a change of $36 \pm 9$ per cent $(P<0.01)$, and from 17 to $22 \mathrm{mmHg}$ (2.3 to $2.9 \mathrm{kPa}$ ) in group 3 , an increase of $33 \pm 6$ per cent $(P<0.001)$ (Tables 2 to 4$)$. Again there was no significant difference $(P>0.8)$ between the groups.

\section{E. Praecordial acceleration}

In group I, the maximum amplitude of the praecordial accelerocardiogram (DE) decreased significantly by an average value of 10 \pm 4 per cent $(P<0.05)$ while in groups 2 and $3 \mathrm{DE}$ increased insignificantly by $8.5 \pm 6$ per cent $(P>0.5)$ and $4 \pm 4$ per cent $(P>0.3)$, respectively (Tables 2 to 4). The response in the normal subjects differed significantly from that in the patients with aortic stenosis $(P<0.02)$ and from that in those with myocardial disease $(P<0.01)$, but there was no significant difference between the response of group 2 and that of group $3(P>0.6)$.

Individually, 50 per cent of the patients in each of groups 2 and 3 showed an abnormal response, i.e. a significant increase in DE. Our data were, therefore, closely examined to see if any haemodynamic differences existed between the patients with a normal response and those with an abnormal response. In neither group 2 nor group 3 did the two subgroups differ significantly with respect to the percentage changes in heart rate, left ventricular systolic pressure, aortic diastolic pressure, or left ventricular end-diastolic pressure (Tables 5 and 6). Though, in the patients with myocardial disease, the subgroup of patients with a significant increase in praecordial acceleration had a mean increase in left ventricular maximum dp/dt of 24 per cent compared with an increase of 7.5 per cent 
TABLE 5 Haemodynamic data in subgroups of patients with aortic stenosis (group 2)

\begin{tabular}{|c|c|c|c|c|c|c|c|c|c|c|}
\hline Case & $\begin{array}{l}\Delta \text { Heart } \\
\text { rate } \\
(\%)\end{array}$ & $\begin{array}{l}\Delta L V \text { syst. } \\
\text { press. } \\
(\%)\end{array}$ & $\begin{array}{l}\Delta \text { Ao diast. } \\
\text { press. } \\
(\%)\end{array}$ & $\begin{array}{l}\Delta L V \max . \\
d p / d t \\
(\%)\end{array}$ & $\begin{array}{l}\Delta L V E D P \\
(\%)\end{array}$ & $\begin{array}{l}\text { Resting } \\
L V \max \\
d p / d t \\
(m m H g / s)\end{array}$ & $\begin{array}{l}\text { Resting } \\
\text { LVEDP } \\
(m m H g)\end{array}$ & $\begin{array}{l}\text { Resting } \\
\text { cardiac } \\
\text { index } \\
(l / m i n \text { per } \\
\left.m^{2}\right)\end{array}$ & $\begin{array}{l}\text { Resting } \\
\text { aortic } \\
\text { valve } \\
\text { gradient } \\
(\mathrm{mmHg})\end{array}$ & $\begin{array}{l}\text { Ao. valve } \\
\text { area } \\
\left(\mathrm{cm}^{2}\right)\end{array}$ \\
\hline \multicolumn{11}{|c|}{ Group $2 A$ (abnormal response) } \\
\hline LB & +23.5 & +14.0 & +26.0 & +55.5 & +87.0 & 1890 & 24 & 2.72 & 34 & 1.13 \\
\hline RC & +4.5 & +6.0 & +13.0 & +12.5 & +11.0 & 1600 & 18 & 4.18 & 79 & 0.72 \\
\hline JD & +12.0 & +33.0 & +24.0 & +16.5 & +65.0 & 1330 & II.5 & 3.80 & Io & - \\
\hline AM & +12.0 & +17.0 & +15.0 & +24.0 & +61.0 & 500 & 11.5 & 2.40 & 60 & 0.53 \\
\hline TW & +2.5 & +4.0 & +11.0 & +8.0 & 0 & 1820 & 15 & 3.40 & 87 & 0.52 \\
\hline AW & $+I I .5$ & +9.5 & + II.0 & +23.5 & 0 & 1580 & 24 & 3.49 & 49 & 0.95 \\
\hline Mean & $1+11.0$ & +14.0 & +18.5 & +23.0 & +37.0 & 1450 & I7 & 3.27 & 53 & 0.77 \\
\hline SEM & 3.0 & 4.0 & 3.0 & 7.0 & 15.5 & 205 & 2.5 & 0.26 & 12 & $0.1 \mathrm{I}$ \\
\hline \multicolumn{11}{|c|}{ Group $2 B$ (normal response) } \\
\hline GB & +7.5 & +12.0 & +7.0 & +36.0 & +15.0 & 1870 & 20 & 1.72 & 35 & 0.43 \\
\hline AC & +27.0 & +26.0 & +19.0 & +35.0 & +36.0 & I780 & 14 & I.87 & 38 & 0.65 \\
\hline PD & $+\mathrm{I} .0$ & +2.0 & +21.0 & +22.0 & +52.0 & 1560 & $2 \mathbf{I}$ & 2.90 & 76 & 0.60 \\
\hline TL & +19.0 & +39.0 & +36.0 & +48.0 & - & 2150 & 一 & 3.10 & 77 & 1.10 \\
\hline HS & +7.0 & +15.0 & +18.0 & +5.0 & - & 2500 & - & 3.30 & 43 & 0.90 \\
\hline AT & +8.0 & +7.0 & +8.0 & +14.0 & +24.0 & 1450 & $2 \mathrm{I}$ & 2.16 & 85 & 0.40 \\
\hline Mean & $1+11.5$ & +17.0 & +18.0 & +27.0 & +32.0 & 1885 & 19 & 2.59 & 53 & 0.68 \\
\hline SEM & 4.0 & 6.0 & 4.0 & 6.5 & 8.0 & 160 & 2.0 & 0.25 & II.0 & $0.1 \mathrm{I}$ \\
\hline \multicolumn{11}{|c|}{ Group $2 A$ versus group $2 B$} \\
\hline $\mathbf{P}$ & $\begin{array}{c}>0.9 \\
\text { NS }\end{array}$ & $\begin{array}{c}>0.6 \\
\text { NS }\end{array}$ & $\begin{array}{r}>0.8 \\
\text { NS }\end{array}$ & $\begin{array}{r}>0.7 \\
\text { NS }\end{array}$ & $\begin{array}{r}>0.7 \\
\text { NS }\end{array}$ & $\begin{array}{r}>0.1 \\
\text { NS }\end{array}$ & $\begin{array}{r}>0.6 \\
\text { NS }\end{array}$ & $<0.05$ & $\begin{array}{r}>0.9 \\
\text { NS }\end{array}$ & $\begin{array}{c}>0.5 \\
\text { NS }\end{array}$ \\
\hline
\end{tabular}

Conversion factor from Traditional to SI Units: I $\mathrm{mmHg} \approx 0.133 \mathrm{kPa}$.

in the remainder, this difference was not significant $(P>0.3)$. There were also no significant differences between the subgroups with respect to resting $\mathrm{dp} / \mathrm{dt}$, aortic valve gradient, or aortic valve area. However, the patients with aortic stenosis who responded to handgrip with an increase in praecordial acceleration had a significantly higher resting cardiac index, 3.27 as against $2.59 \mathrm{l} / \mathrm{min}$ per $\mathrm{m}^{2}(\mathrm{P}<0.05)$ (Table 5). Furthermore, there was a significant linear correlation between the percentage change in praecordial acceleration and resting cardiac index (Fig. 2). Those patients with myocardial disease who responded abnormally in terms of DE had a significantly lower resting left ventricular end-diastolic pressure, $14(\mathrm{I} .9 \mathrm{kPa})$ as against $20 \mathrm{mmHg}(2.7 \mathrm{kPa})$ $(\mathbf{P}<0.02)$ (Table 6). Patients with a history of a previous myocardial infarction and those with dyskinetic areas did not differ from the remainder in their accelerocardiographic response to handgrip.

\section{Discussion}

The increases in heart rate, blood pressure, left ventricular end-diastolic pressure, and maximum $\mathrm{dp} / \mathrm{dt}$ which we observed are comparable to those described in previous work (Fisher et al., 1973; Grossman et al., 1973; Helfant et al., 1971; Kivo- witz et al., I971; Krayenbuehl et al., 1972, 1973; Payne et al., 1973). Furthermore, the effects of handgrip in each of our three groups were of a similar order of magnitude (Table 4). Therefore, the differences in the response of the praecordial accelerocardiogram between the groups cannot be attributed to differences in the level of isometric exercise achieved, even though in the normal subjects handgrip was performed using a strain gauge dynamometer (Hume et al., 1974) while the patients gripped a sphygmomanometer cuff. Our normal subjects were significantly younger than the patients in groups 2 and 3 but, in the various groups, there was no relation between age and the change in DE during handgrip. The subjects in group I were not studied during cardiac catheterization but, in Io patients of groups 2 and 3 studied on the day before the procedure, the change in DE was similar to that which occurred during catheterization.

The interesting and unexpected finding which emerges from this study is that 50 per cent of patients in each of groups 2 and 3 responded abnormally to the stress of isometric exercise with an increase in DE. This subgroup of patients could not be distinguished from the remainder in terms of 
TABLE 6 Haemodynamic data in subgroups of patients with myocardial disease

\begin{tabular}{|c|c|c|c|c|c|c|}
\hline Case & $\begin{array}{l}\Delta \text { Heart } \\
\text { rate } \\
(\%)\end{array}$ & $\begin{array}{l}\Delta L V \text { syst. } \\
\text { press. } \\
(\%)\end{array}$ & $\begin{array}{l}\Delta L V \max . \\
d p / d t \\
(\%)\end{array}$ & $\begin{array}{l}\triangle L V E D P \\
(\%)\end{array}$ & $\begin{array}{l}\text { Resting } \\
L V \max . d p / d t \\
(m m H g / s)\end{array}$ & $\begin{array}{l}\text { Resting } \\
L V E D P \\
(m m H g)\end{array}$ \\
\hline \multicolumn{7}{|c|}{ Group $3 A$ (abnormal response) } \\
\hline TG & +28.5 & +34.5 & +20.0 & +97.0 & 1820 & 15 \\
\hline JK & +6.5 & +11.5 & +12.0 & +25.0 & II20 & 16 \\
\hline FM & +14.0 & +31.0 & +47.5 & +68.0 & 2150 & II \\
\hline $\mathbf{D M}$ & +4.0 & +17.0 & +10.0 & +15.0 & 1390 & 13.5 \\
\hline JR & +16.5 & +45.0 & +47.0 & +75.0 & 845 & 12 \\
\hline JS & +2.0 & +4.0 & -3.0 & +25.0 & 1850 & 20 \\
\hline GT & +10.5 & +25.0 & +9.0 & +17.0 & 1190 & 12 \\
\hline GW & +12.5 & +16.5 & $+5 \mathrm{I} .0$ & +8.0 & 1840 & 12 \\
\hline Mean & +12.0 & +23.0 & +24.0 & +41.0 & 1525 & 14 \\
\hline SEM & 3.0 & 5.0 & 7.5 & 12.0 & 160 & I \\
\hline \multicolumn{7}{|c|}{ Group ${ }_{3} B$ (normal response) } \\
\hline JA & +18.0 & +30.0 & 0 & +5.0 & 2000 & 20 \\
\hline JC & +2.0 & +13.0 & +8.5 & +33.0 & 1780 & 15 \\
\hline DC & +9.5 & +29.0 & +5.5 & +33.0 & 1070 & 15 \\
\hline WF & +8.5 & +11.0 & +10.5 & +35.0 & 960 & 18.5 \\
\hline $\mathrm{JL}$ & +7.0 & +18.5 & +18.5 & +17.0 & 2360 & 18 \\
\hline $\mathrm{CM}$ & +3.0 & - & +4.5 & +29.0 & I 100 & $3 I$ \\
\hline $\mathbf{J M}$ & +5.0 & +8.5 & +15.0 & +27.0 & 870 & 22 \\
\hline $\mathrm{CP}$ & +22.5 & +24.0 & -3.5 & +22.0 & 850 & 18 \\
\hline Mean & +9.5 & +19.0 & +7.5 & +25.0 & 1375 & 20 \\
\hline SEM & 2.5 & 3.5 & 2.5 & 3.5 & 205 & 2 \\
\hline \multicolumn{7}{|c|}{ Group $3 A$ versus group $3 B$} \\
\hline $\mathbf{P}$ & $\begin{array}{l}>0.5 \\
\text { NS }\end{array}$ & $\begin{array}{l}>0.5 \\
\mathrm{NS}\end{array}$ & $\begin{array}{l}>0.3 \\
\text { NS }\end{array}$ & $\begin{array}{l}>0.2 \\
\text { NS }\end{array}$ & $\begin{array}{l}>0.5 \\
\text { NS }\end{array}$ & $<0.02$ \\
\hline
\end{tabular}

Conversion factor from Traditional to SI Units: I $\mathrm{mmHg} \approx 0.133 \mathrm{kPa}$.

the adequacy of the test (Tables 5 and 6). The only interventions which have been shown to increase $\mathrm{DE}$ are dynamic exercise (Hume et al., 1974) and increases in myocardial contractility induced by positively inotropic drugs (Reuben and Littler, 1973), particularly sympathomimetic amines. Though previous workers have shown an improvement in various indices of myocardial function during handgrip and have concluded that the normal response includes an increase in contractility (Grossman et al., 1973; Helfant et al., 1971; Kivowitz et al., 1971; Krayenbuehl et al., 1972; 1973), there is some evidence to suggest that this improvement in left ventricular performance is exclusively caused by the chronotropic effects of handgrip (Krayenbuehl and Rutishauser, I973). The maximum amplitude of the praecordial accelerocardiogram is insensitive to changes in heart rate induced by atrial pacing (Reuben and Littler, 1973) and it also does not increase during handgrip in normal subjects (Hume et al., 1974). Our observation that a significant proportion of cardiac patients shows an increase in $\mathrm{DE}$ during handgrip suggests that these patients increase left ventricular contractility during handgrip independently of any effects of tachycardia. It seems to us that the most likely explanation is that these patients activate the beta adrenergic nervous system in response to the stress of isometric exercise.

In normal subjects beta adrenergic blockade does not greatly modify the cardiovascular response to isometric exercise and it has been concluded that the response in these subjects is relatively independent of this division of the autonomic nervous system (Macdonald et al., 1966; Shaver et al., 1972). Plasma catecholamine levels have been shown to increase excessively during dynamic exercise in patients with cardiac failure (Braunwald, 1965; Braunwald and Chidsey, 1965; Chidsey, Harrison, and Braunwald, 1962; Harrison and Chidsey, 1962) and angina pectoris (Gazes, Richardson and Woods, 1959; Richardson, 1963). It seems plausible, therefore, that certain patients with impaired myocardial reserve might respond to the stress of isometric exercise with a compensatory increase in beta adrenergic drive. There is also evidence of increased beta adrenergic tone at rest in patients with cardiac failure (Braunwald and Chidsey, 1965; Chidsey et al., 1965; Gaffney and Braunwald, 1963) and in patients with aortic 
stenosis (Hamer and Fleming, 1969). Robinson and his colleagues have presented evidence that, in physiological situations in which sympathetic tone is increased at rest, the adrenergic nervous system plays a greater role in the mediation of certain circulatory reflexes (Robinson et al., 1966). This may be applicable to the circulatory response to handgrip in those patients in whom sympathetic tone is appreciable at rest.

Our observation that the patients with aortic stenosis who failed to show an increase in praecordial acceleration were those with a low cardiac index (Table 5, Fig. 2) is interesting. A reduction in cardiac index in aortic stenosis is a late event in the natural history of the disease (Dexter et al., 1958) and is said to signify the presence of left ventricular failure (Goldberg, Bakst, and Bailey, 1954; Gorlin et al., 1955). It is possible that, when myocardial impairment reaches a critical level, the compensatory increase in sympathetic stimulation during handgrip becomes insufficient to increase left ventricular contractility and the response, in terms of the praecordial accelerocardiogram, reverts to 'normal'. Previous work has shown a reduction in the responsiveness of the heart to electrical stimulation of the sympathetic nerves in advanced, experimental cardiac failure (Covell, Chidsey, and Braunwald, 1966). The pathological counterpart of this phenomenon might be the reduction in myocardial norepinephrine stores which has been described in severe cardiac failure (Braunwald, 1965; Braunwald and Chidsey, 1965; Chidsey et al., 1963, 1965).

The patients with myocardial disease who failed to increase praecordial acceleration during handgrip had a significantly higher resting left ventricular end-diastolic pressure than those who did (Table 6). While this would conform to our previous suggestion that patients with poor myocardial function are unable to increase praecordial acceleration during handgrip despite increased beta adrenergic activation, the mechanism underlying a raised left ventricular end-diastolic pressure in coronary artery disease is not altogether clear and may equally well be an impairment of left ventricular diastolic compliance rather than pump failure (Bristow, Van Zee, and Judkins, 1970). However, in the patients with aortic stenosis, in whom altered compliance is even more likely, there was no difference in left ventricular end-diastolic pressure between the two subgroups of patients. Nevertheless, we do not feel justified in concluding that patients with coronary heart disease and a raised left ventricular end-diastolic pressure necessarily have impaired systolic function of the left ventricle. An association between increased left ventricular filling pressure and the presence of segmental abnormalities of contraction in coronary artery disease has been demonstrated (Herman and Gorlin, 1969) and, more recently, handgrip has been shown to induce or accentuate localized wall motion abnormalities (Ludbrook, Karliner, and O'Rourke, 1974). This could be the explanation for our observation that the patients with higher left ventricular end-diastolic pressures failed to increase praecordial acceleration during handgrip (Table 6).

Although the discussion of our results is largely speculative, the hypotheses advanced in this section may readily be tested and should serve to stimulate further studies into the mechanisms by which cardiac patients adapt to stress.

\section{References}

Bew, F. E., Pickering, D., Sleight, P., and Stott, F. D. (1971). 'Pixie' cardiography. Accelerometer applications to phonocardiography and displacement cardiography in childhood. British Heart fournal, 33, 702.

Braunwald, E. (1965). The control of ventricular function in man. British Heart fournal, 27, I.

Braunwald, E., and Chidsey, C. A. (1965). The adrenergic nervous system in the control of the normal and failing heart. Proceedings of the Royal Society of Medicine, 58, I063.

Bristow, J. D., Van Zee, B. E., and Judkins, M. P. (1970). Systolic and diastolic abnormalities of the left ventricle in coronary artery disease. Circulation, 42, 219.

Chidsey, C. A., Braunwald, E., and Morrow, A. G. (1965). Catecholamine excretion and cardiac stores of norepinephrine in congestive heart failure. American fournal of Medicine, 39, 442.

Chidsey, C. A., Braunwald, E., Morrow, A. G., and Mason, D. T. (1963). Myocardial norepinephrine concentration in man. Effects of reserpine and of congestive heart failure. New England fournal of Medicine, 269, 653.

Chidsey, C. A., Harrison, D. C., and Braunwald, E. (1962). Augmentation of the plasma norepinephrine response to exercise in patients with congestive heart failure. New England Fournal of Medicine, 267, 650 .

Chung, D. C. W., Chamberlain, J. H., and Seed, R. G. F. L. (1974). The effect of haemodynamic changes on maximum blood flow acceleration at the aortic root in the anaesthetized open-chest dog. Cardiovascular Research, 8, 362.

Covell, J. W., Chidsey, C. A., and Braunwald, E. (1966). Reduction of the cardiac response to post-ganglionic sympathetic nerve stimulation in experimental heart failure. Circulation Research, 19, 51 .

Dexter, L., Harken, D. E., Cobb, L. A., Novack, P., Schlant, R. C., Phinney, A. O., and Haynes, F. W. (1958). Aortic stenosis. Archives of Internal Medicine, ror, 254.

Fisher, M. L., Nutter, D. O., Jacobs, W., and Schlant, R. C. (1973). Haemodynamic responses to isometric exercise (handgrip) in patients with heart disease. British Heart fournal, 35, 422.

Gaffney, T. E., and Braunwald, E. (1963). Importance of the adrenergic nervous system in the support of circulatory function in patients with congestive heart failure. American fournal of Medicine, 34, 320.

Gazes, P. C., Richardson, J. A., and Woods, E. F. (1959). Plasma catecholamine concentrations in myocardial infarction and angina pectoris. Circulation, 19, 657. 
Goldberg, H., Bakst, A. A., and Bailey, C. P. (1954). The dynamics of aortic valvular disease. American Heart Fournal, 47, 527.

Gorlin, R., and Gorlin, S. G. (I95I). Hydraulic formula for calculation of the area of the stenotic mitral valve, other cardiac valves, and central circulatory shunts. American Heart fournal, 4I, I.

Gorlin, R., McMillan, I. K. R., Medd, W. E., Matthews, M. B., and Daley, R. (I955). Dynamics of the circulation in aortic valvular disease. American fournal of Medicine, 18,855 .

Grossman, W., McLaurin, L. P., Saltz, S. B., Paraskos, J. A., Dalen, J. E., and Dexter, L. (1973). Changes in the inotropic state of the left ventricle during isometric exercise. British Heart fournal, 35, 697.

Hamer, J., and Fleming, J. (1967). Effect of propranolol on left ventricular work in aortic stenosis. British Heart fournal, 29, 871.

Harrison, D. C., and Chidsey, C. A. (1962). Assessment of sympathetic nervous system activity during exercise in congestive heart failure (abstract). Circulation, 26, 729.

Helfant, R. H., DeVilla, M. A., and Meister, S. G. (I97I). Effect of sustained isometric handgrip exercise on left ventricular performance. Circulation, 44, 982.

Herman, M. V., and Gorlin, R. (1969). Implications of left ventricular asynergy. American fournal of Cardiology, 23, 538.

Hume, L., Irving, J. B., and Reuben, S. R. (1974). The effects of beta blockade on the praecordial accelerocardiogram. Scottish Medical fournal, 19, 200.

Judkins, M. P. (1968). Percutaneous transfemoral selective coronary arteriography. Radiologic Clinics of North America, $6,467$.

Kivowitz, C., Parmley, W. W., Donoso, R., Marcus, H., Ganz, W., and Swan, H. J. C. (197I). Effects of isometric exercise on cardiac performance. The grip test. Circulation, 44, 994.

Krayenbuehl, H. P., and Rutishauser, W. (1973). Hemodynamic consequences and clinical significance of the handgrip test. European fournal of Cardiology, I, 5 .

Krayenbuehl, H. P., Rutishauser, W., Schoenbeck, M., and Amende, I. (1972). Evaluation of left ventricular function from isovolumic pressure measurements during isometric exercise. American fournal of Cardiology, 29, 323.

Krayenbuehl, H. P., Rutishauser, W., Wirz, P., Amende, I., and Mehmel, H. (I973). High fidelity left ventricular pressure measurements for the assessment of cardiac contractility in man. American fournal of Cardiology, 31, 415 .
Ludbrook, P., Karliner, J. S., and O'Rourke, R. A. (1974). Effects of submaximal isometric handgrip on left ventricular size and wall motion. American fournal of Cardiology, 33, 30 .

Macdonald, H. R., Sapru, R. P., Taylor, S. H., and Donald, K. W. (1966). Effect of intravenous propranolol on the systemic circulatory response to sustained handgrip. American fournal of Cardiology, 18, 333.

Noble, M. I. M., Stubbs, J., Trenchard, D., Else, W., Eisele, J. H., and Guz, A. (1972). Left ventricular performance in the conscious dog with chronically denervated heart. Cardiovascular Research, 6, 457.

Noble, M. I. M., Trenchard, D., and Guz, A. (1966a). Left ventricular ejection in conscious dogs. I. Measurement and significance of the maximum acceleration of blood from the left ventricle. Circulation Research, 19, 139.

Noble, M. I. M., Trenchard, D., and Guz, A. (1966b). Effect of changing heart rate on cardiovascular function in the conscious dog. Circulation Research, 19, 206.

Payne, R. M., Horwitz, L. D., and Mullins, C. B. (1973). Comparison of isometric exercise and angiotensin infusion as stress test for evaluation of left ventricular function. American fournal of Cardiology, 31, 428.

Reuben, S. R., and Littler, W. A. (I973). Praecordial accelerometry: an indirect assessment of left ventricular performance. European fournal of Clinical Investigation, 3, 324.

Richardson, J. A. (1963). Circulating levels of catecholamines in acute myocardial infarction and angina pectoris. Progress in Cardiovascular Diseases, 6, 56.

Robinson, B. F., Epstein, S. E., Beiser, G. D., and Braunwald, E. (I966). Control of heart rate by the autonomic nervous system. Studies in man on the inter-relation between baroreceptor mechanisms and exercise. Circulation Research, 19, 400.

Shaver, J. A., Martin, C. E., Reddy, P. S., Thompson, M. E., and Leon, D. F. (1972). Effects of selective autonomic blockade on cardiovascular responses to isometric exercise (abstract). Circulation, 46, Suppl. II, 219.

Winter, P. J., Deuchar, D. C., Noble, M. I. M., Trenchard, D., and Guz, A. (1967). Relationship between the ballistocardiogram and the movement of blood from the left ventricle in the dog. Cardiovascular Research, 1, 194.

Requests for reprints to Dr. Stuart R. Reuben, Department of Cardiology, Western General Hospital, Edinburgh $\mathrm{EH}_{4} 2 \mathrm{XU}$. 